\title{
SWIMMING CRAWL STYLE: THE EFFECT OF PURE OR PROGRESSIVE METHOD AND LEVEL OF BODY FAT
}

\author{
Subagyo*, Guntur, Abdul Alim \\ Universitas Negeri Yogyakarta, Indonesia \\ *e-mail: subagyo@uny.ac.id
}

\begin{abstract}
The crawl style is a freestyle which is frequently used in national and international competitions. However, this swimming style requires much attention because of its complexity. On the other hand, it is very beneficial despite the facts that athletes do not like it. The objectives of this research were to examine the significant difference between two teaching methods: the pure and the progressive teaching methods. The sample of this study were 32 male students from a junior high school in Yogyakarta. The sample were divided into two groups with 16 students in the control group and 16 students in the experimental group. The data in this study were collected through a measurement on the students crawl style basic movements and the body fat level. The data were subsequently analyzed with independent sample t-test and correlation by the means of SPSS version 23. The result showed that there was a significant difference of basic movement score between the pure method and progressive method learning with $p$ value of $0.03<0.05$. The level of fat was not a constraint on both methods of teaching. High and low fat were positively correlated on both methods with the strength of the correlation was very high. In conclusion progressive method was better method to teach crawl style compared to the pure method of teaching because it gave many benefits for learners compared to the pure method teaching, regardless the level of the body fat.
\end{abstract}

Keywords: teaching, pure method, progressive method, body fat, crawl style

\section{GAYA RENANG MERANGKAK: PENGARUH METODE MURNI ATAU PROGRESIF DAN TINGKAT LEMAK TUBUH}

\begin{abstract}
Gaya renang merangkak adalah gaya bebas yang baik digunakan dalam kompetisi nasional dan internasional. Akan tetapi, gaya renang ini membutuhkan banyak perhatian karena kerumitannya. Di sisi lain, gaya berenang jenis itu sangat bermanfaat meskipun para atlet tidak menyukainya. Tujuan penelitian ini adalah untuk mendeskripsikan signifikansi perbedaan efektivitas antara metode pembelajaran murni dan metode pembelajaran progresif. Penelitian ini merupakan penelitian eksperimental dengan pendekatan kuantitatif. Sampel penelitian sejumlah 32 siswa laki-laki SMP Negeri di Yogyakarta, sampel semua anggota kelas. Sampel penelitian dibagi dalam dua kelompok 16 subyek untuk tiap grup. Pengumpulan data lapangan dengan melakukan pengukuran gerakan dasar gaya bebas. Analisis data dengan uji-t sampel independen, korelasi dengan program SPSS versi 23. Hasil penelitian menunjukkan bahwa ada perbedaan yang signifikan antara metode murni dan metode pembelajaran progresif dengan nilai $p(0,03)<0,05$. Tingkat lemak tidak menjadi kendala pada kedua metode pembelajaran. Lemak tinggi dan lemak rendah berpengaruh positif untuk kedua metode dengan tingkat korelasi sangat kuat. Simpulan penelitian ini menunjukkan bahwa metode progresif lebih baik untuk mengajarkan gaya merangkak karena memberi manfaat lebih banyak bagi peserta didik dibandingkan dengan metode pembelajaran murni, tanpa perlu membedakan tingkat lemak tubuh.
\end{abstract}

\section{Kata Kunci: pembelajaran renang, metode murni, metode progresif, tubuh lemak, gaya bebas}

\section{INTRODUCTION}

Swimming is known as water sports, which may be in the form of games or competitions in swimming pool or nature water such as sea, lake or river. Swimming is a kind of exercise or movement in the water commonly executed without the usage of any tools (Grant, 2017). Sport has a very strategic function in the establishment and enhancement of body growth. Sport requires training or coaching that allows a systematic effort to facilitate better achievement. 
Ericsson (2016) explains that education is a procedure of change in a better direction, to improve the physical and psychological quality of the trainers. As already known, that sport is essentially not only to maintain and improve their health, but also aims to achieve excellence in sports. However, it takes time and hard work to developsportsmanship.

Taking the National Sports in Indonesia as an instance, it has a goal to maintain and improve the health and fitness, human qualities, as well as instill moral values discipline, and raise the dignity and honor of the nation (Ma'mun, 2015). Sports do not only involve physical education but also recreation (Haydon, Pinder, Grimshaw, \& Robertson, 2018). Specifically, physical education is part of national education that aims to develop the physical activity of students by achieving a balanced physical growth and adequated physical resistance (Taufiqurriza, 2012).Physical education should also facilitate the development of mental health (Henriksen, Schinke, Moesch, McCann, Parham, Larsen, \& Terry, 2019). Moreover, the purpose of physical education is also to cultivate positive attitude and maturation mental attitude through a variety of physical activities in order to nurture discipline, honesty, cooperation, and respect for others,.

Swimming is mostly included in the physical education curriculum. Swimming sports require special facilities and infrastructure, unlike other sports which is relatively easier to be held. This includes, namely float, slide, continuity of motion, water obstacles, the breathing air, and glide.Results of learning to swim might be determined by many factors, such as the teacher, lesson material, quality of equipment, and the teaching method. The physical education teachers and students' belief of the aim of the swimming might also a factor (Morais, Silva, Marinho, Lopes, \& Barbosa, 2017). It has been found that physical activity and fitness leads to improved health adn therefore the outcome of physical education should direct the orientation to fitness (Richards \& Padaruth, 2017).

Swimming skills should be taught using appropriate methods. Principles and practical application of the most basic psychological skills can also be taught on young athletes (Shaari, Hooi, \& Siswantoyo, 2019). The level of fitness as the outcome of the sports should be measured using an instrument for examples
Fitmate version 2.2, Wellness technology division cosmed, and by supporting devices such as treadmills. Further, the level of fatigue during exercise of swimmingmight be measured using a polar heart rate monitor brand and Stopwatch (BT Butterfly 60 Japan) (Kriswanto, Setijono, \& Mintarto, 2019). Another thing that is often not considered in the teaching is less considering the individual characteristics of students. Students have different characteristics from each other, both the characteristics of the physical or psychological (Siswantoyo \& Kuswarsantyo, 2017). Special physical factors need to get the attention of their own, because factors such as age, weight, height and gender. Other physical aspects that may influence learning outcomes pool is profile factor of the body, especially the thickness of body fat, because the thickness of the body associated with body fat percentage. Holliday (Morrison, Cairney, Eisenmann, Pfeiffer, \& Gould, 2018) argues that the outline of the human body is composed of $40 \%$ muscle, organ $10 \%, 15-30 \%$ adipose tissue, $15 \%$ of the skeleton, and $25 \%$ in the form of a liquid. The average percentage of fat for males between 15 and $17 \%$ while for women $25 \%$. Thus the woman has greater buoyancy than men (Dhapola \& Verma, 2017; Shen et al., 2015).

The selection method of teaching adopted by teachers to teach swimming skills in particular sport by segmenting that is dividing the learning material in several sections and then combined into one movement (Siswantoyo \& Kuswarsantyo, 2017).

There are concerns regarding swimming teaching is influenced by several factors. Among these factors are the choice of teaching methods for swimming. It is necessary to consider the differences in the characteristics of the students, especially profile of the learner's body in the form of body fat composition. Body fat affects the buoyancy and buoyancy influence in learning to swim. Many factors have an effect on improvement in swimming performance. Although there might be a long listing of research studies about special components that affect the performance, it seems little is known about the performance in young learners.

In attempt to answer the question of the teaching method of the crawl style, different positions have been found in the development of elite athletes throughout a variety of sports, 
or inspecting the overall performance balance at some point of elite swimmers' careers in precise nations. It is confirmed that cumulative education hours are important for intelligence development at an early age in swimmers. In addition, some diploma of sports specialization is fundamental to improve elite-level skill improvement. On the other hand, it has been located that a greater extent of discipline-specific education and competition, and an prolonged involvement in institutional talent promoting programs, all through adolescence seems no longer necessarily be related with greater success in senior international elite game. It also has been located a low conversion charge from elite junior athletes to elite senior athletes in swimming. About one third of worldwide pre-junior athletes reappeared as senior athletes, confirming the difficulties of predicting later success based on early identification and choice. Until now there is any study which showed the perfect teaching method according to the crawl style.

This research will focus on the reason of knowing which most effective methods between the pure teaching method and the progressive teaching method, therefore in permitting athletes and coaches to achieve the expected performance.

\section{METHODS}

This research is an experimental research in crawl style swimming. Köroğlu \& Yiğiter (2016) explain that experimental research is a study intended to determine whether there are results or not for a given treatment subject. In this case the operational definition of the dependant variables are: a) the percentage of body fat is a result of measurement using a caliper folds of the skin to get the percentage of body fat as measured by body fat in areas subscapular or triceps and then convert to a table for each age, b) learning outcomes crawl swimming style is the distance that can be achieved by students with the correct technique.

\section{Population and Sample}

In this study population is taken from a public junior high school in Yogyakarta who were taking extra-curricular of swimming ( $n$ $=32$ persons). In this study, the sample used is the student who were not able to swim yet. In addition, the students were categorised into high fat presentation and low fat percentage. Of the samples that have met the criteria set by the researcher, then the sample is inserted into the respective groups in accordance with the study design have been made, to be taught by pure or progressive method.

\section{Procedures of pure and progressive methods}

The only difference between the two teaching method was showed on the way how to associate the basic techniques of crawl swimming. There are four basic elements to be learned by students, these were: (1) move on the stomach, (2) learn arm and leg movement, (3) learn to breathe, and (4) the complete crawl swims.

For the pure method of learning, the teacher began by one element sequently, for example move on the stomach until the student could perform it perfectly, and then continued the next part. The students were asked to combine all elements at the end. By observation it was found that some elements for example the first elements are forgotten. Nevertheless for the progressive method learning is a logical sequence, we learn an element today, and tomorrow for the next session we give feedback and add a new element. Each time we must imperatively recapture the first technique until it is a good goal to allow the elements to be integrated very quickly.

Data from the study will be presented below is the data pool value learning outcomes conducted by the judge. Rate judge by grating that has been made and has been tested techniques include swimming movements of crwal style: (1) the body position, (2) leg movements technique, (3) arm movement technique, (4) motion technique breathing. This study used two methods: (1) Pure learning method (learning one by one movement and the combined lesson will be studied at the last lesson after performed the first basics movements); (2) Progressive learning method (every lesson combined the movements lent progressively).

\section{Data Collection Instrument}

The facts series instruments in this study were: a) monitoring of fat athletes, b) assessment of the basic swimming movements (techniques and tactics). The key pointers for a profitable crawl summing pool can be determined by way of measuring the distance (Sammoud, Negra, 
Chaabene, Bouguezzi, Moran, \& Granacher, 2019). That validity is a measure that suggests the degree of validity of the instrument (Meggs $\&$ Chen, 2019). To take a look at the validity of the instrument with a scale note, reliability need to first be examined through the assessor (Mooney, Corley, Godfrey, Osborough, Newell, Quinlan, \& ÓLaighin, 2016). Test the validity of the instrument using the Correlation Total section.

Data were analyzed using independent sample t-Test and correlation with SPSS version 23. The software helped us to calculate if there is any significant difference between the two methods afforded.

\section{FINDINGS AND DISCUSSION Findings}

The records analyze used to be completed first through Kolmogorov-Smirnov and Levine test to test normality and homogeneity of the distribution. Due to the fact normality take a look at is a performed take a look at with the purpose to assess the distribution of records in a team of statistics or variables, whether the facts distribution is commonly allotted or not. Normality Test . is beneficial for figuring out information that has been accrued in regular distribution or taken from a norm population.

Normal distribution is used in a number of distributions in statistics, and speculation testing assumes the normality of data. The normal distribution is one of the chance distributions that is necessary in statistical analysis. This distribution has parameters in the shape of mean and standard deviation. From the statistics above it can conclude that the population was once regular dispensed with $\mathrm{p}$ value most effective than .05 (Asymp. With sig. (2-tailed) the normality of variables are respectively the following: progressive method (.260), pure method (.957), high fat (.623), low fat (.515) all of the values were superior more than .05 which means that the data were normal distributed. However the homogeneity test proved the significant value with $p(.784)>.05$ which means that data were homogenize (Kolmogorov-Smirnov and Levine Test).

Table 1. Test Normality and Homogeneity of Pure, Progressive Method Score, and Level Fat Subjects

\begin{tabular}{lcccc}
\hline Parameters & Progressive Method & Pure Method & High Fat & Low Fat \\
\hline$N$ & 16 & 16 & 16 & 16 \\
Mean & 3.889 & 3.082 & 3.658 & 3.302 \\
Std. Deviation & .905 & 1.093 & 1.080 & 1.086 \\
Asymp. Sig. (2-tailed) & .013 & $.200 \mathrm{c}$ & .183 & .108 \\
Monte Carlo Sig. (2-tailed) & .260 & .957 & .623 & .515 \\
99\% Confidence Interval & & & & \\
Lower Bound & .249 & .952 & .610 & .502 \\
Upper Bound & .272 & .963 & .635 & .528 \\
Test of Homogeneity of Variances & .784 & & & \\
\hline
\end{tabular}

Table 2. Independent Samples Test Pure Method and Progressive Method

\begin{tabular}{llllll}
\hline & $\begin{array}{l}\text { Levine's Test } \\
\text { for Equality of } \\
\text { Variances }\end{array}$ & \multicolumn{2}{l}{ t-test for Equality } & & \multicolumn{1}{l}{$\begin{array}{l}\text { 95\% Confidence } \\
\text { Interval of Different }\end{array}$} \\
\cline { 2 - 7 } & $\mathrm{F}$ & sig. & $\mathrm{t}$ & $\mathrm{df}$ & sig. (2-tailed) \\
\hline Test equal variances assumed & & & -2.273 & 30 & .030 \\
Equal variances not assumed & .655 & .425 & -2.273 & 28.992 & .031 \\
\hline
\end{tabular}


Table 3. Paired Samples Correlations of Pure, Progressive Method Score, and Level Fat Subjects

\begin{tabular}{lllcl}
\hline & Variables & $\boldsymbol{N}$ & Correlation & Sig. \\
\hline Pair 1 & Low fat \& Pure method & 16 & .953 & .000 \\
Pair 2 & Low fat \& Progressive method & 16 & .867 & .000 \\
Pair 3 & High fat \& Pure method & 16 & .962 & .000 \\
Pair 4 & High fat \& Progressive method & 16 & .940 & .000 \\
\hline
\end{tabular}

To evaluate the independent sample t-test we proceeded on the following hypotheses. The assumption was based on the following hypothesis: (1) there is no different between pure and progressive methods $\left(H_{0}\right) ;(2)$ there is significant different between pure and progressive $\left(H_{a}\right)$.Test Equal variances assumed (.030) and Equal variances not assumed (.031) all them are inferior to .05 which support that the null speculation is rejected and the $2^{\text {nd }}$ speculation which means that there is huge special between pure and progressive method is accepted. The researcher concluded that there is a significant different between the pure method and the progressive method. In this study the progressive method was found as a good method to teach crawl style because it is very benefit for learners.

In this study the subjects had a different morphology from the point of view of body mass: there were individuals who had a high body mass index and the others who presented a very low body mass index. The question was, is there an influence on learning to swim? So that the problem was to test if to have low or high fat can influence the pure method score or the progressive method score. There is a strong positive correlation between low fat \& pure method $(r=.953)$; a positive correlation was found between low fat $\&$ progressive method $(r=.867)$; a high correlation was also found between high fat $\&$ pure method $(r=.962)$; at the end a strong positive correlation was found between high fat $\&$ progressive method $(r=$ .940). The results showed that whether a subject had a very high or low body mass index was not a problem. The influences on the learning of the nation are the same. There is no reason to say $I$ don't or can't swim because I'm fat or I'm lean.

\section{Discussion}

The result found in this study was to determine best method between pure method and progressive method. The result above showed that the progressive method was found as a good method to allow athlete to research the good performance more than the pure method.In addition to teaching sport-specific skills, coaches should train and instill existence skills such as leadership, teamwork, and persona constructing to their athletes. These are important capabilities to promote the development of high-quality human functioning.

A growing body of research on coaches of excessive performance athletes has printed their role entails more than producing a notable win-loss report and champion athletes. Bradley \& Conway (2016) said that to emerge as a top athlete requires time, dedication and cautiously planned training.Optimum adaptation to education requires the cautious balancing of stress andrecovery. The needs of high-level recreation require the athlete to commit a growing quantity oftime to their recreation in order to compete correctly.

Chen et al. (2017) showed that common practices to help elite pupil athletes (ESA) can be identified in one-of-a-kind countries and cities around the world. As athletic overall performance and profession development of elite athletes are carefully linked, it is necessary to put in force and support research into elite athletes and their careers, particularly ESAs' psychosocial determinants of twin profession development. Every training can improve performance whether it respected the training aspects (Shaari et al., 2019)

Nutrition is an indispensable component to any athlete's education and performance program. In adults the stability between energy intake and electricity demands is imperative in training, recovery, and performance. In young athletes the demands for education and performance remain however should be a secondary center of attention in the back of the demands related with retaining the suitable boom and maturation. Even if in that current research we did not find any negative aspect from the high fat, Arciero, 
Miller, \& Ward (2015) in their research showed that performance in staying power activities is established upon the maximal aerobic power, the share of that electricity that can be sustained and the availability of substrates (carbohydrates $[\mathrm{CHO}]$ and fats). The results from data analysis showed that there is difference in the percentage of high and low body fat but this difference was without any negative impact on the performance for teaching summing crawl.

Calculations performed statistical analysis variable showed that, there was no significant interaction between method of teaching and the body fat on learning outcomes crawl swimming style. There was no negative impact as athlete is fat or loss fat on the two methods of learning.

\section{CONCLUSION}

The constant exercise of swimming by young folks improves their balance and/or the functioning of their physique parts, enhances body functions and neutralizes the harm brought on via sedentary lifestyles that is so attribute of this type of adolescents. The paper pursuits at taking gain of the experience gathered in teaching the crawl approach to young athletes. The experiment has involved two groups: high fat and low fat from high school, who began every movement from null, like: to float, glide and breathe in water.

The learn about was once carried out at some point of three months and protected one lesson of 60 minutes three times per week. The evaluation of the degree at which the swimming method had been acquired via the topics was once done every four weeks. Through swimming practice, younger men and women have the possibility to improve their physical condition, motor abilities and self-esteem; they can additionally improve certain capabilities that can help them. Based on the data analysis, to test the hypotheses that have been made, so in this study, it can be concluded that the hypothesis that progressive method teaching is more efficient than pure method teaching was confirmed, regardless the body fat level. Coach trainer and physical education and sport could afford that new approach to make quick learning and performance, without asking the learner's body fat level.

\section{AKNOWLEDGMENTS}

The researcher thanks to the participants on this study who allow following all the sessions of the experiment as sample research.

\section{REFERENCES}

Arciero, P. J., Miller, V. J., \& Ward, E. (2015). Performance enhancing diets and the PRISE protocol to optimize athletic performance. Journal of Nutrition and Metabolism, 2015, 1-39. doi:10.1155/2015/715859.

Bradley, J. L., \& Conway, P. F. (2016). A dual step transfer model: Sport and nonsport extracurricular activities and the enhancement of academic achievement. British Educational Research Journal, 42(4), 703-728. doi:10.1002/berj.3232.

Chen, Y. W., Li, C. H., Yang, C. D., Liu, C. H., Chen, C. H., Sheu, J. J., ... Hsu, C. Y. (2017). Low cholesterol level associated with severity and outcome of spontaneous intracerebral hemorrhage: Results from Taiwan stroke registry. PLoS ONE, 12(4), 1-15. doi:10.1371/journal.pone.0171379.

Dhapola, M. S., \& Verma, B. (2017). Relationship of body mass index with agility and speed of university players. International Journal of Physical Education, Sports and Health, 4(2), 313-315. http://www. kheljournal.com/archives/?year $=2017 \& \mathrm{v}$ $\mathrm{ol}=4 \&$ issue $=2 \&$ part $=\mathrm{F} \&$ ArticleId $=898$.

Ericsson, I. R. (2016). Effects of motor skills training and daily physical education: Research results in the Swedish Bunkeflo project. International Journal of Physical Education, 2, 1-12. http://www. schulsport.m-m-sports.com/wissenschaft/ front_content.php?idart=2569.

Grant, M. C. (2017). Land based resistance training and youth swimming performance. International Journal of Sports and Exercise Medicine, 3(4), 1-11. doi:10.23937/2469-5718/1510064. 
Haydon, D. S., Pinder, R. A., Grimshaw, P. N., \& Robertson, W. S. P. (2018). Overground-propulsion kinematics and acceleration in elite wheelchair rugby. International Journal of Sports Physiology and Performance, 13(2), 156162. doi:10.1123/ijspp.2016-0802.

Henriksen, K., Schinke, R., Moesch, K., McCann, S., Parham, W. D., Larsen, C. H., \& Terry, P. (2019). Consensus statement on improving the mental health of high performance athletes. International Journal of Sport and Exercise Psychology, O(0), 1-8. doi:10.10 80/1612197x.2019.1570473.

Köroğlu, M., \& Yiğiter, K. (2016). Effects of swimming training on stress levels of the students aged 11-13. Universal Journal of Educational Research, 4(8), 1881-1884. doi:10.13189/ujer.2016.040818.

Kriswanto, E. S., Setijono, H., \& Mintarto, E. (2019). The effect of cardiorespiratory fitness and fatigue level on learning ability of movement coordination. Cakrawala Pendidikan, 38(2), 320-329. doi:10.21831/cp.v38i2.24565.

Ma'mun, A. (2015). Development of the educational sport in Indonesia: The policy study based on the law of national sports system. ATIKAN: Jurnal Kajian Pendidikan, 5(1), 33-48. doi:http:// journals.mindamas.com/index.php/ atikan/article/view/4.

Meggs, J., \& Chen, M. A. (2019). Competitive performance effects of psychological skill training for youth swimmers. Perceptual and Motor Skills, 126(5), 886-903. doi:10.1177/0031512519852533.

Mooney, R., Corley, G., Godfrey, A., Osborough, C., Newell, J., Quinlan, L. R., \& ÓLaighin, G. (2016). Analysis of swimming performance: Perceptions and practices of US-based swimming coaches. Journal of Sports Sciences, 34(11), 997-1005. doi:10 $.1080 / 02640414.2015 .1085074$.
Morais, J. E., Silva, A. J., Marinho, D. A., Lopes, V. P., \& Barbosa, T. M. (2017). Determinant factors of long-term performance development in young swimmers. International Journal of Sports Physiology and Performance, 12(2), 198205. doi:10.1123/ijspp.2015-0420.

Morrison, K. M., Cairney, J., Eisenmann, J., Pfeiffer, K., \& Gould, D. (2018). Associations of body mass index, motor performance, and perceived athletic competence with physical activity in normal weight and overweight children. Journal of Obesity, 2018(3598321), 1-10. doi: $10.1155 / 2018 / 3598321$.

Rezaee, M., Ghasemi, A., \& Momeni, M. (2012). Visual and athletic skills training enhance sport performance. European Journal of Experimental Biology, 2(6), 2243-2250. http://www.pelagiaresearchlibrary.com/.

Richards, K. A. R., \& Padaruth, S. (2017). Motivations for pursuing a career in physical education: The rise of a fitness orientation. Journal of Physical Education, Recreation \& Dance, 88(4), 40-46. doi:10 .1080/07303084.2017.1280438.

Sammoud, S., Negra, Y., Chaabene, H., Bouguezzi, R., Moran, J., \& Granacher, U. (2019). The effects of plyometric jump training on jumping and swimming performances in prepubertal male swimmers. Journal of Sports Science and Medicine, 18(4), 805-811. http://www. jssm.org.

Shaari, J. S., Hooi, L. B., \& Siswantoyo, S. (2019). The effectiveness of psychological skills training program on netball shooting performance. Cakrawala Pendidikan, 38(1), 174-187. doi:10.21831/ cp.v38i1.23206

Shen, S., Li, J., Guo, Q., Zhang, W., Wang, X., Fu, L., .. \& Niu, K. (2015). Body mass index is associated with physical performance in suburb-dwelling older Chinese: A crosssectional study. PLoS ONE, 10(3), 1-11. doi:10.1371/journal.pone.0119914. 
Siswantoyo, S. \& Kuswarsantyo, K. (2017). Development of "Tari Pencak Silat Nusantara" For developing and conserving pencak silat as a nation cultural asset towards globalization. IOP Conference Series: Materials Science and Engineering, 180(012179), 1-6. doi:10.1088/1757-899X/180/1/012179.
Taufiqurriza, H. (2012). Tingkat keterampilan dasar permainan sepak bola pada siswa sekolah dasar. [The basic skill level of a soccer game in elementary school students]. Journal of Physical Education, Sport, Health and Recreations, 1(1), 1618. doi:10.15294/active.v1i1.266. 